ment, rural hygiene, drainage of swamps and stamping out foci of infection, port and river sanitation and housing. A department of industrial hygiene was established in August 1940, while nutrition problems are handled by the National Nutrition Administration founded in February 1940.

\section{Zoological Society of London: New Secretary}

Dr. S. A. Neave, C.M.G., O.B.E., director of the Imperial Institute of Entomology, has been elected honorary secretary of the 7 oological Society of London to fill the vacancy caused by the resignation of Prof. Julian Huxley. Dr. Neave will hold office until April 1943, when the next annual general meeting will be held. Dr. Neave's work, especially in economic entomology, is well known. He was naturalist to the Geodetic Survey of Northern Rhodesia during 1904-5; entomologist to the Katanga Sleeping Sickness Commission during 1906-8 and entomologist to the Entomological Research Committee (Tropical Africa) during 1909-13. From 1918 until 1933 he was honorary secretary of the Royal Entomological Society and was its president in $1934-35$.

\section{Alphonse Francois Renard (1842-1903)}

The Belgian geologist Alphonse François Renard, who with Murray reported on the rock deposits from the bottom of the sea collected by the "Challenger" expedition, was born at Renaix in East Flanders on September 27, 1842. Educated at Rome for the Church, during 1866-69 he was superintendent at the Collège de la Paix at Namur, and then entered the Jesuit College at the old abbey of Maria Laach in the Eifel. Taking up the study of geology and chemistry, in 1874 he was made professor of those subjects at the College of the Belgian Jesuits at Louvain and a few years later was made a curator of the Royal Natural History Museum at Brussels. Though ordained a priest in 1877, he abandoned his intention of entering the Society of Jesus and separated from Rome, resigned his post at Louvain in 1882 and in 1888 was appointed professor of geology in the University of Ghent, a post he held until his death. In conjunction with Vallée-Poussin (1827-1904) he wrote on the plutonic rocks of Belgium. The Geological Society in 1885 awarded him the Bigsby Medal. He died at Brussels on July 9, 1903.

\section{The Night Sky in October}

The moon is new on October 10d. $04 \mathrm{~h} .06 \mathrm{~m}$. and full on October 24d. $04 \mathrm{~h}$. $05 \mathrm{~m}$. U.T. The following conjunctions will occur during the month: Oct. 3d. 16h., Jupiter in conjunction with the moon, Jupiter $3^{\circ} \mathrm{N}$.; Oct. $27 \mathrm{~d}$. $1 \mathrm{~lm}$., Saturn in conjunction with the moon, Saturn $3^{\circ}$ N.; Oct. 3ld. 05h., Jupiter in conjunction with the moon, Jupiter $3^{\circ} \mathrm{N}$. Occultations of naked-eye stars during the month are as follows, the times referring to Greenwich :

\begin{tabular}{|c|c|c|c|c|c|}
\hline d. & $\begin{array}{l}\text { h. } \\
03\end{array}$ & $\begin{array}{r}m . \\
44 \cdot 3\end{array}$ & 18 & Leonis & $\boldsymbol{R}$ \\
\hline 26 & 21 & $52 \cdot 3$ & $\gamma$ & Tauri & $D$ \\
\hline & 23 & $02 \cdot 1$ & & Tauri & $\boldsymbol{R}$ \\
\hline 27 & 03 & $44 \cdot 7$ & $\theta$ & Tauri & $D$ \\
\hline & 04 & $24 \cdot 6$ & & Taur1 & $\boldsymbol{R}$ \\
\hline 27 & 04 & $37 \cdot 8$ & 75 & Tauri & $\boldsymbol{R}$ \\
\hline 27 & 07 & $51 \cdot 7$ & $a$ & Tauri & $D$ \\
\hline
\end{tabular}

On October 11 Mercury is in inferior conjunction and on October 26 will be at an elongation fevourable for northern observers, rising about $2 \mathrm{~h}$. before the sun. Venus is too close to the sun to be observed during the month. Mars is in superior conjunction on October 6 and is not well placed for observation. Jupiter is favourably placed for observation after midnight, and Saturn, near Aldebaran, rises early in the night, southing about $3 \mathrm{~h}$. in the middle of the month.

\section{Announcements}

Sir D'Arcy Thompson, professor of natural history in the University of St. Andrews, has been elected president of the Royal Scottish Geographical Society, in succession to Lord Rosebery.

The Lord President of the Council has appointed Sir Lawrence Bragg, Prof. J. E. Lennard-Jones, Dr. A. McCance and Sir Raymond Streat to be members of the Advisory Council to the Committee of the Privy Council for Scientific and Industrial Research from October 1. Dr. G. M. B. Dobson and Mr. S. K. Thornley will retire from the Council on completion of their terms of office on September 30 .

By an Order of the Committee of Privy Council, made after consultation with the Medical Research Council and with the president of the Royal Society, Prof. D. Keilin, Quick Professor of Biology in the University of Cambridge, and Sir Henry H. Dale, retiring director of the National Institute for Medical Research, have been appointed to be members of the Medical Research Council in succession to Prof. L. J. Witts and Prof. C. R. Harington, who retire in rotation on September 30. By the same Order, Sir Charles Glen MacAndrew, M.P., has been appointed to be a member of the Council in succession to the Right Hon. James Gray Stuart, M.P., also from October 1.

Dr. Harrison E. Howe, editor of the Journal of the American Chemical Society, Industrial and Engineering Chemistry, and a trustee of Science Service, has been awarded the Chemical Industry Medal for 1942 by the American Society of Chemical Industry.

MR. F. H. WYNNE retired from the post of H.M. chief inspector of mines on September 20, on reaching the age limit. He is succeeded by Mr. J. R. Felton, who has been the deputy chief inspector since the end of 1937.

Dr. Félix Aguilar, director of the National Observatory, La Plata, Argentina, writes that one of his colleagues, Mr. Gualberto M. Iannini, has undertaken to compute a definite orbit of Comet Whipple, $1942 a$. He would be very grateful for data, especially from observatories in the northern hemisphere.

THE opening meeting of the new session of the Iron and Steel Institute will be held on October 13, at 2.30 p.m., in the lecture theatre of the Institution of Electrical Engineers, Savoy Place, Victoria Embankment, London, W.C.2, when the president, Mr. W. M. Selvey, will present a short address. This will be followed by the presentation of the Melchett Medal for 1942 to Dr. Arno Carl Fieldner, chief of Fuels and Explosives Services, United States Bureau of Mines. As Dr. Fieldner cannot be present, the medal will be accepted on his behalf by the United States Embassy. The Melchett Lecture, entitled "The Analysis and Testing of Coal in Relation to its Properties and Utilization", will, in Dr. Fieldner's absence, be delivered in the form of a talking film of himself reading it, which will be reproduced in the lecture theatre. 